\title{
Determinat Factors Corellated with IVA Test Among Couple of Childbearing Age
}

\author{
Puji Wahyuni1). Christin HiyanaTunggaDewi ${ }^{2}$ ), Ribkhalthaldhayanti²) \\ pujiwahyuni2297@gmail.com \\ Ministry of Health Polytechnic Semarang \\ Midwifery Degree Program Applied Magelang
}

\begin{abstract}
Background: Visual Inspection with Acetic Acid (VIA) or Inspeksi Visual Asam asetat (IVA) in Indonesian is a visual test using an acidic solution of vinegar and iodine Lugol solution on the cervix and sees the color change after it is smeared. Advantages IVA Tests are easy, inexpensive, effective, results can be instantly known, and the way is very simple.

Purpose: to determine the factors associated with the participation of IVA tests in couples of childbearing age. The benefits of the study may have an effect to support the participation of IVA tests in couples of childbearing age.

Methods: Type of research used in this research Analitic. Cross-sectional design used. Univariate analysis to know the frequency distribution of each variable. Bivariate analysis using Spearman Rank test. The population of 303 EFA, Determining the sample with slovin to 75 respondents. The sampling technique uses the proportional stratified random sampling, and the way sampling by computerization.

Results: Based on the results of research enough knowledge level of 56\% (42 respondents). Attitudes that agree with the participation of the IVA test is $62.7 \%$ (47 respondents), husband support IVA test that is $54.7 \%$ (41 respondents), health support worker IVA test that is 64\% (48 respondents), respondents get access to information $53.3 \%$ (40 respondents), respondents who are willing to follow the IVA test is $65.3 \%$ (49 respondents). In Spearman Rank test there is a relationship between knowledge level with IVA test participation, $\rho(0.048)$. There is no relationship between attitude with IVA test participation, $\rho(0,145)$. There is a relationship between the support of the husband with the participation of the IVA test, $\rho(0.000)$. There is no correlation between the support of health personnel with the participation of the IVA test, $\rho$ (0407).

Conclusion: Based the results of the study is expected Midwives support and improve counseling about the IVA test, respondents can increase of knowledge about IVA test information and husband always support the wife.

keyword: Knowledge, attitude, husband support, the support of health workers, IVA test

1) Student of Midwifery Study Program of Magelang, Poltekkes Kemenkes Semarang

2) Lecturer of Midwifery Study Program of Magelang, Poltekkes Kemenkes Semarang
\end{abstract}

Background. Morbidity and mortility rate is one of the main reasonof cervical cancer. (Rasjidi, 2009). Most of adult women in the world survive this type of cancer. Based from International Agency for Research on Canter (IARC) $85 \%$ of cancer case in the world which in total 493.000 followed by 273.000 death case, happens in the developing country. WHO mentioned, there are 490.000 women in the world have cervical cancer every year. Indonesia has the highest case of cervical cancer among 
other type of cancer, the spreading of this cancer is accumulated in Jawa and Bali for about 92,4\% (Savitri, 2015).

Cervical cancer is a type of malignant tumor of the epithelial lining of the cervix or the cervix. This cancer can occur because the surface cells experienced a doubling or sometimes as ulcers are asymptomatic smelling vaginal discharge and bleeding. These malignant cells can spread beyond the pelvis and spread far through the blood vessels, for example to the lungs, liver or bones. It also attacks the female reproductive organs(Savitri, 2015), Cervical cancer becomes malignant because there are abnormal cells which effect the body's tissues to function properly. (Rahayu, 2015)

According to (RI, nd)that the number of cervical cancer in Indonesia in 2016 reached 1,739 cases, with the number of positive Acetic Acid Visual Inspection is 73453 or $5.15 \%$ Acetic Acid Visual Inspection examination in women in Indonesia. Bali has the highest rate of Acetic Acid Visual Inspection which is $19.57 \%$, followed by DKI Jakarta with $12.09 \%$, and West Nusa Tenggara with $11.42 \%$.

Central Java is one of the provinces in Indonesia which has large numbers of cases of cervical cancer whoreceived quite high ratings from 8 out of 34 provinces in Indonesia. According to(Jateng, nd) The highest percentage of positive Acetic Acid Visual Inspection is Groboganie $27.27 \%$, followed by the Temanggung $23.71 \%$, and $22.48 \%$ Tegal. While the results of the data of RSUD Temanggung showed that there were 133 cases of cervical cancer in 2016 which is a referral patients from various health centers in the district of Temanggung.
Cancer that has spread to the organ that is in stage IV, this cancer is the most severe type and should be given medical treatment with radiation and chemotherapy, but the ability to maintain viability after 5 years of treatment is between $0 \%$ and $12 \%$ (Rahayu, 2015)Based on interviews of hospital personnel about patients referred from health centers in the district of Temanggung that most patients come to the hospital already in a state of advanced stage which is stage 3 and 4 . It can be said that patients with cervical cancer are late to check on themselves this makes their recovery rate goes between $0 \%$ and $12 \%$, it can only be cured with radiation and chemotherapy actions done by the hospital. (Rahayu, 2015)

Acetic Acid Visual Inspection test is a visual test using a solution of acetic acid and Lugol iodine solution to the cervix and observethe changing colour that occur after it is smeared.(Rasjidi, 2009)

According to research conducted by Maharsie\&Indarwati (2012) in (Saputri, 2014)that low coverage of early detection is becausethe lack of education that will affect the person in receiving the information thusthey become less in knowledge. Less at knowledge will also affect a person's attitude. Attitude is a collection of symptoms in response to the stimulus and the readiness or willingness to act. The attitude that possess the highest levels that the responsibility for what she has believed and risk-taking on the attitudes that have been taken. The attitude in the act involves the thoughts, feelings, concerns and psychiatric symptoms (Notoatmodjo, 2010)

Many women are not aware of and understand the IVA, it causes morbidity, and malignancy are still 
common

(Rasjidi, 2009)PuskesmasBulu is one of the health centers have IVA program with lower IVA examination. Puskesmas Bulu has the lowest positive result which is about164 it is $21.34 \%$, followed by PuskesmasKrangganwhich is 172 with $59.30 \%$ positive IVA and IVA in Puskesmas Pringsurat which is 227 with positive $12.78 \%$ (Waterford, 2011)

Preliminary Study will be held on October 28, 2017 with interviews of midwives in Puskesmas Bulu, there are four villages with a lower consciousness of IVA test that arePutat $0 \%, 0 \%$ Ngimbrang village, village Malangsari $0 \%$, and $0 \%$ Bansari village.

From the description above problems can increase awareness of fertile age couple in the early detection of cervical cancer, so it could be understanding and increase the knowledge of the author doing research on "Factors Associated with Participation IVA test on fertile age couple".

Objective, The population in this research that are fertile age couples inNgimbrang village, District Bulu, Temanggung regency in 2017 as many as 308 people.

Methods. This study uses analytical study with design of research which is used is cross sectional. The sampling technique stratified proportional random sampling by 75 respondents.

The independent variables in this study are knowledge, attitudes, husband support, the support of health workers, and access to information, The dependent variable is IVA test participation of fertile age couples. Material study on knowledge, attitude, husband support, the support of health workers, and access to information. Instruments which is used is a questionnaire sheet. Implementation of research in Ngimbrang village, Temanggung regency in September to May 2018. After the data collected then do the processing, and the data analysis which is used is by testSpearman Rank. with the help of SPSS soft were.

\section{Result and Discussion.}

\section{Result}

1. Knowledge Factor on fertile age couples

The level of knowledge about IVA test is mostly used in enough categories, namely $56 \% \quad(42$ respondents). most respondents answered correctly on a questionnaire about the statement IVA test can be cured if it is knownearlieris $\quad 99 \% \quad$ (74 respondents). However, most respondents who answered incorrectly aboutIVA test with positive results is recommended to check every month is $79 \%$ (59 respondents).

2. Attitude factors on fertile age couples

Respondents' attitudes about the participation of most existing IVA test on agreed categories, namely $62.7 \%$ (47 respondents). Most respondents agree on a questionnaire about I am willing to take the IVA test because it can detect cervical cancer by $99 \%$ (74 respondents). However, the majority of respondents did not agree on a questionnaire about willingness of an IVA test for knowing other people have positive IVA or advanced cervical cancer found which is about $73 \%$ (55 respondents) 
3. Factors of husband support in fertile age couples

Husband support among respondents who participate is about $54.7 \%$ (41 respondents). Most husbands support IVA test from informative support of my husband IVA allowed me to take the test is about 92\% (69 respondents). But most husbands do not support the emotional support of my husband reminded IVA test schedule is $36 \%$ (27 respondents).

4. Factors from health workers in fertile age couples

Support from health workers on the respondents on most existing IVA test participation in supporting categories, namely 64\% (48 respondents). Most of the health workers give emotional support ofThe health worker convinced mothers the importance of IVA test,Health workers are willing to listen to grievances of a mother when she wanted to has IVA test and Health workers servefriendly and politely isabout $96 \% \quad(72$ respondents). Yet most of health professionals who do not support is in the support of the assessment of health workers notify IVA test results to a close associate of the mother is $49 \%$ (37 respondents).

5. Factors of accessing information on fertile age couples

Access to information on the respondents' participation on IVA test who is in the category yes is $53.3 \%$ (40 respondents). Most of the respondents have access to information through media given by midwivesare $88 \%$ (66 respondents). However, most respondents who do not have access to information through the journal mediaare $88 \%$ (66 respondents).
6. Participation on IVA test on fertile age couples

The participation in the most respondents who have IVA test in category yes is $65.3 \% \quad(49$ respondents). Most mothers who are willing to take the IVA test are $71 \%$ (53 respondents), and those who choose puskesmas as a place for treatment are about $67 \% \quad(50$ respondents).

7. Analysis of knowledge factor related to the participation of IVA test in fertile age couple, most respondents who stated sufficient knowledgelevel and take the IVA testare $25(59.5 \%)$ of respondents, while 17 respondents with sufficient knowledge but do not take the IVA test. Using the Spearman rank test it is obtained that $\rho$ Value is $0,048 \leq$ 0.1 which means Ho is rejeted and $\mathrm{Ha}$ is accepted, so that there is a relationship between knowledge and participation on IVA test, with a change towards the positive coefficient correlation about 0.229 in range from 0.20 to 0.399 which gives a low correlation.

8. Analysis onattitude related to participation on IVA test

Most respondents who agreed and followed the IVA test are $35(74.5 \%)$ of respondents, while 12 respondents agreed but did not take the test. Using the Spearman rank test,it is obtained that $\rho$ Value is $0,145 \leq 0.1$ which means that Ho is accepted and $\mathrm{Ha}$ is rejected, so that there is no relationship between attitude and participation on IVA test, with changes towards the positive coefficient correlationis about 0.170 in rangefrom 0.00 to 0.199 which only give a very weak relation. 
9. Analysis of husband's support related to mother's participation on IVA test on fertile age couples

The majority of respondents who earn husband's support as many as 35 respondents are willing to take the test while 6 respondents who supported bytheir husband but did not take the test IVA. Using the Spearman rank test, it is obtained that $\rho$ Value is $0,000 \leq 0.1$ which means Ho is rejected Ha is accepted, so that there is relation between husband support and the participation of IVA test, with a correlation of coefficient changes towards the positive is 0,496 in range from $\leq 0.40$ to 0.599 which gives sufficient relation.

10. Analysis of factors on support of health workers with the participation of IVA test on fertile age couples Respondents who receive support of health workers and willingly to take the test are 33 respondents while 15 respondents did not take the test. Using the Spearman rank test it is obtained that $\rho$ Value is $0,407 \leq 0.1$ which means that Ho is accepted and $\mathrm{Ha}$ is rejected, thus there is no relation between health professionals support and the participation of IVA test, with the change towards the positive correlation coefficient is 0.097 in range from 0.00 to 0.199 which just gives a low relation.

11. Analysis of factors onrelation of accessing information of IVA test and participation of IVA test in fertile age couples.

Most respondents who said yes and followed the IVA test are 30 (75\%) of respondents, while 10 respondents did not take the test. Using the Spearman rank test, it is obtained that $\rho$ Value is $0,029 \leq 0.1$ which means $\mathrm{Ho}$ is rejected $\mathrm{Ha}$ is accepted, so that there is a relationbetween access to information with the participation of IVA test, with the change towards the positive correlation coefficient is 0.252 in range from 0.20 to 0.399 which provides a low correlation.

\section{Discussion}

1. Knowledge

Based on research on factors related to the participation of the test on 75 repondents. The level of knowledge of women who arein fertile age couples inNgimbrang villagewho have the sufficient level of knowledge are 42 rspondents (56\%).

Respondents who were able to answer correctly on IVA tests can be cured if it is known from the beginning are $99 \%$ (74 respondents). It is concluded that the perception of women to recover is high because they do not want a positive IVA test to spreadand become malignant. In line with the theory according to Rahayu (2015; 21, 23), IVA for early detection of cervical cancer, if detected early, it can minimize the cancer and can be cured.

A small portion of respondents who answered correctly in a statement on IVA test with positive results is recommended to check every month is $79 \%$ (59 respondents). This is because the respondents have not learned that IVA test with a positive result is checked one year. Efforts of IVA couseling in the village of Ngimbrang is still lowthis makes repondents do not know about it yet.

The statistical test was obtained that $p$-value is 0.048 , statistically there is a significant correlation between knowledge and participation of IVA test. Also 
supported also by studies conducted by (Masturoh, 2016)which results in the calculation of the chi-square test showed $\mathrm{p}$ value is $0.023<0.05$, so that the $\mathrm{Ha}$ is accepted and $\mathrm{Ho}$ is rejected. This shows that there is a significant relation between knowledge and fertile age women's behavior in cervical cancer screening with the IVA test. This shows that the influence between knowledge and behavior in the examination of fertile age women on IVA test included in the low category. It can be concluded that women who are in fertile age and have good knowledge do cervical cancer screening with IVA test. Conversely,a fertile age women who have poor knowledge are not willing to take IVA test.

Further research of (Maharsie, 2013)the results of the calculation of correlation with the values obtained using the Chisquare the $\mathrm{P}$ value is $0.000<0.05$. Thus, there is a significant relationship between knowledge about cervical cancer with the participation of IVA test. From the above conclusion, it has been known that the low participation of mothers in IVA Test in the Village while most of the knowledge is high. This proves that the higher the knowledge gained, the higher the mother's awareness to have the IVA test. From the description above can be concluded that a high level of knowledge does not guarantee a person to have good manners. This is compatible with the theory in the research of Notoamodjo(Maharsie, 2013)that in addition to knowledge, there are many factors that influence the behavior which are trust, beliefs, values, the facility or health facilities and behavior of health workers.

2. Attitude

$$
62.7 \% \quad \text { (47 respondents). }
$$

Respondents who agreed about I am willing to take the test because it can detect cervical cancer are 99\% (74 respondents). This shows the positive attitude of respondents. In accordance opinions by (Dewi, 2011) A positive attitude about the object is a sentence that is supportive or siding to an object or a positive statement.

Further research on I did not do the test because of fear of pain with tools that inserted into the female organs about $68 \% \quad(51$ respondents). This is because the mothers have never checked IVA so they do not feel it directly only heard stories of people who have completed the IVA test. According to research by (Sari, 2016) that fertile age women are still many who do not have the awareness to follow IVA examination for several reasons, such as embarrassment, fear, and do not feel the need so that makes them less of a passion for the checks of IVA. 0,145 of $p$ value was obtained from statistical test it is said that there is no statistically significant correlation between attitude to the participation of IVA test. Supported also by studies conducted by (Aziz, 2011)that the results of Chi Square test calculation, there is no significant relation between attitude and action of WPSTL about Pap smear and IVA with the acquisition $\mathrm{p}$ value $=0.302(\mathrm{p}$ $<0.05$ ). This can happen because the attitude is a reaction or response to a stimulus that is still closed.

Further research conducted by (Lisminawati, 2016)the results of 
the analysis of Kendal Tau is known that $p$ value of $0.021>0658$ which concluded that there was no significant relation between interest in the participation of women in IVA test after counseling. This study shows that is not the interest of a mother would affect participation in a IVA test, this is due to the presence of several other factors affecting such as economic factors that affect the cost or the perception of mothers who do not understand that the examination of IVA test can be done with no cost. Another factors that can influence areno chance, local culture, family support, personality, motivation, occupation, age, living environment, experience, resources, maternal education and knowledge about IVA test itself.

However, different research conducted by(Melva, yusrawati Hasibuan, 2014) test fisher conducted on attitudes and behavior of fertile age women in conducting IVA test for cervical cancer screening results obtained with $\mathrm{p}$ value less than $0.05(0.005<0.05)$, so the $\mathrm{Ha}$ is accepted and $\mathrm{Ho}$ is rejected. This shows that there is significant influence between attitudes and behavior of fertile age women in examinations with IVA test for cervical cancer. This indicates a negative attitude caused by the respondent never get the information about IVA of health personnel so that the respondents are not concerned with the IVA examination. According to(Notoatmodjo, 2010) that attitude is a readiness or willingness to act as an appreciation of the object.

\section{Support husband}

Support from husband on respondents' participation in IVA test is mostly used in the support category is $54.7 \%$ (41 respondents). Most husbands support their wife to take the test of IVA, it is seen in my husband IVA allowed to take the test as many as $92 \% \quad(69$ respondents). This is a form of support that the husband give to the wife in following IVA test and did not forbid his wife. According to the theory house in prasetyowati that the support of information provided to be used by someone in tackling the problems faced, including giving advice, guidance, ideas or other information that is required and this information can be passed on to others who may face the same problem or nearly the same.

However, a small portion husband support the emotional support regarding my husband reminded IVA test scheduleis $64 \%$ (48 respondents). This is because the husband has not been informed about the test and the schedule of IVA test, every time IVA test is held the husbands usually only agree to follow his wife to her health without knowing the schedule of each visit.

The statistical test was obtained that $\rho$ Value is 0,000 $\leq 0.1$ statistically significant there is a relationship between husband support and the participation of IVA test. Also supported by research conducted by (Ning, 2017)which results in the calculation Chi Square test that there is a significant relationship between husband support and the participation of IVA examination in women of fertile age couples in Puskesmas Pringapus Semarang regency with $p$ value $0.006<0.05$. In research conducted by (Lisminawati, 2016)Based on 
Chi Square test which has been done, the value of the $\mathrm{P}$ value is $(0.001)$ $<(0.05)$ so that the $\mathrm{Ha}$ is accepted stating that there is a relations between low family support withIVA visits in Puskesmas East Halmahera District of Semarang in 2010. so it can be said that the role of husband is very large. in the family, and is very beneficial for health.

Furthermore, according to research conducted by (Yustisianti, 2017)using Chi Square statistic test showed that there is a relation between a husband's support with behavioral ofwomen in fertile age to do IVA examination at the Puskesmas Kasihan I Bantul, the pvalue is $0.015(\mathrm{p} \leq \alpha=0.05)$, so it can be concluded that Ha is accepted and Ho is rejected, which means there isa relation between husband's support and behavioral of women in fertile age to doIVA examination at Puskesmas Kasihan I Bantul

4. Health workers' support

Category supports namely $64 \%$ (48 respondents). Most of the health workers to support as much as $96 \% \quad(72$ respondents $)$ to emotional support onThe health worker convinced her of the importance of IVA test. This is a form of support to encourage respondents to take IVA test.For more on health workers willing to listen to grievances of mother when she wanted to take IVA test and the instrumental support ofHealth workers to serve friendly and politely

It is also a form of support for health workers is the task of the health workers who will always listen to the complaints of the patient as well as serving with friendly and courteous. The corresponding statement of support by(RI, nd)that officers should be sensitive to the feelings and client's concerns before, during and after an examination. Midwives who provide counseling should be as complete as possible to ensure that mothers can make decisions based on the information obtained. Women may be embarrassed or do not want to be checked because she has to show the vagina. Poise, attention and competence can help client's trust and encourage to continue to come to the clinic according to her reproductive health need.

However, fraction supporting existing health workers in support of the assessment inform health workers to other IVA test results with other health workers at 53\% (40 respondents). In this case respondents are less aware of health workers know the secrecy rules that have to maintain the confidentiality of the patient from anyone unless authorized patients andby legislation.

The statistical test was obtained that $\rho$ Value is 0,407 $\leq 0.1$ statistically significant there was no correlation between health professionals support and the participation of IVA test. Also supported by research conducted by (Parapat, S, Sc, Saraswati, and Epid, 2016)that the calculation results obtained from chi-square test that the $\mathrm{p}$-value is $0.1<0.05$ that there is no connection with the behavior of health workers support and the early detection of cervical cancer with visual acetic acid inspection method. Some women who have close relations with the midwife in village or other health professionals influence a mother's decision to conduct the examination. Support health workers not guarantee the 
participation of the IVA test if it does not suit the wishes of the mother.

In this research, the support of health workers is not related to the participation of IVA test. This is presumably because, the support given to the women in fertile age couples of health workers may be providing information about IVA examination for early detection of cervical cancer. Support is also given in the form of a response or positive response if the responder invites discussion on women's health issues, one of them and IVA test for cervical cancer. And give counseling to the husband in order to increase knowledge about cervical cancer and IVA inspection, so that the husband easily push his wife to do early checks against cervical cancer. In this case it is in the same line with L Green premises theory that the factor of support from health workers is the driving factor or reinforcing a person perform the behavior.

However, different research conducted by (Lailawati, 2016)the Chi-square test was used to support health workers to visit the fertile age couples in screening for cervical cancer using the IVA in the Bojonglor Village, District of Bojong, Pekalongan regency it is obtained that $\mathrm{p}$ value $(, 0.0001)<\alpha$ (0.05) so that $\mathrm{Ha}$ failed to be rejected. This shows that there is a significant relationship between the support of health workers to visit the fertile age couples in screening for cervical cancer using the IVA in the Bojonglor Village, District of Bojong, Pekalongan regency. This shows that almost as fertile age couples support high-low and support of health workers in the
Bojonglor Village, District of Bojong, Pekalongan regency.

5. Access to information

Access to information on the respondents' participation on IVA test is mostly used in the category yes that is $53.3 \%$ (40 respondents). Most of the respondents have access to information through media from midwives as much as $88 \%$ (66 respondents). It is to illustrate that respondents trust completely to the health worker or midwives. However, few respondents have access to information through the printed journal which is $12 \%$ (9 respondents). This is because the majority of respondents are less insight into the science of health. Habits of respondents who are busy with work and not be concerned with the health that only rely on midwives as a model about health without obtaining information through other media.

The statistical test was obtained $\rho$ Value-at 0,029 $0.1 \leq$ statistically significant there is a relation between access to information with the participation of IVA test. Also supported by research conducted by (Masturoh, 2016) that the results of Fisher test calculation that there is significant relation between access to information with fertile age women's behavior in conducting examinations with IVA test for cervical cancer, the results of $p$ value is less than $0.05(0.029<0.05)$.

Furthermore, the research conducted by (Lester, 2016)using the Chi-square test results obtained $\mathrm{p}$ value $0,042<0,05$ so that $\mathrm{Ho}$ is rejected, then there is a relationship between access to information with a willingness fertile age women in the early detection of cervical cancer 
in Puskesmas Manahan Surakarta That study concluded that the exposure of individuals to health information will encourage healthy behavior. Access information is essentially to support or enable the realization of health behavior changing, especially the implementation of early detection of cervical cancer, this factor is called a supporting factor. Through the printed media or electronic media health problems presented in the form of articles, news, discussion, submission of opinions, and so on.

6. Participation on IVA Test

Most of the respondents are willing to take the test IVA as much as $\quad 65.3 \% \quad$ (49 respondents). Respondents were not willing to take the test, it is because of lack of information about IVA test, counseling or education about IVA test is still rarely done in the Ngimbrang ngimbrang so there were respondents who did not know the purpose of the test. Fear is also the reason repsonden not willing to take the test IVA because they hear stories of people who have completed the IVA test without knowing the clear information on the actions to be taken during the examination.

This is in line with research conducted by Yulia (2011) in research conducted by(Lisminawati, 2016)who said that the low participation of women in following the early detection of cervical cancer should be understandable, since behavior for the early detection of cervical cancer is not only influenced by knowledge alone, factors that influence in addition to knowledge of the most prominent factor is the individual's own which are no awareness or willingness to carry out checks and the assumption of individuals associated with aging. Where many young mothers with the knowledge of good and less people believe IVA examination is not important for mothers of young age, but more important for the elderly because it is more risky.

In this case it can be concluded that the majority of respondents are willing to take the test and choose to do the inspection in puskesmas because it is closer. The role of the volunteers could be an intermediary to provide information and encourage mothers to do the inspection IVA.tr

\section{Conclusion and Suggestions.}

\section{Conclusion}

1. Most respondents have enough knowledge level is $56 \% \quad(42$ respondents). The statement largely answered incorrectly, ie $79 \%$ (59 respondents). The low level of knowledge is inhibiting the increased awareness and changes in human behavior. so that still need to be given much information about IVA test.

2. Most of the respondents' attitudes on the agreed participation IVA test that is $62.7 \%$ (47 respondents). The statement largely answered disagree is $73 \%$ ( 55 respondents). This indicates that most respondents agreed to have IVA test. A positive attitude will tend to be better in IVA's participation as a positive attitude tend to approach her actions, please, expect a certain object.

3. Most husbands who supported the participation IVA test that is $54.7 \%$ (41 respondents). Husbands who do not support are 36\% (27 respondents). So the majority of respondents supported the 
husband's support of the IVA test participation.

4. Most of the health workers who supported the participation tests IVA is $64 \%$ (48 respondents). The statement does not support the majority of health workers that $49 \%$ (37 respondents). So that most of the respondents received support from health professionals about the participation IVA test.

5. Most of the respondents who have access to information that is $53.3 \%$ (40 respondents). The statement mostly do not get access to information is $\quad 88 \% \quad(66$ respondents). So most of the respondents have access to information via the midwives about IVA test participation. Access to information affecting the IVA examination for individual exposure to health information will encourage healthy behavior.

6. Most respoonden who are willing to take the test IVA is $65.3 \%$ (49 respondents). The statement mostly not willing to take the test IVA is $33 \%$ (25 respondents). It is still not optimal, it is in because of lack of information about IVA test, counseling or education about IVA test is still rarely done in the village Ngimbrang so there were respondents who do not know the purpose of the test IVA.

7. There is a relation between knowledge and participation in the IVA test on fertile age women, with $\rho$ value $(0.048)<0.1$. This proves that the higher the knowledge gained, the higher the mother's awareness following the IVA test.

8. There is no relation between attitude with IVA test participation in fertile age women, with $\rho(0.145)$ $<0.1$. This is due to the presence of several other factors affecting such economic factors that affect the cost or the perception of mothers who do not understand that this IVA test inspection can be done geratis.

9. There is a relation between husband support the participation of IVA test on fertile age women, with $\rho(0.000)<0.1$. So it can be said that the role of husband is very large. in the family, and is very beneficial for health.

10. There is no relation between support of health workers with the participation of the fertile age couples on IVA test, with $\rho(0,407)$ $<0.1$. Support of health workers do not guarantee the participation of the IVA test if it does not suit the wishes of the mother.

11. There is a relation between access to information with IVA test participation in fertile age couple, with $\rho(0.209)<0.1$. It is said that access to information is essentially to support or enable the realization of health behavior change, especially the implementation of early detection of cervical cancer, this factor is called a supporting factor.

\section{Suggestion}

1. Women of feertile age couples Respondents are expected to unlock insights and knowledge of information about IVA test by reading the leaflets, books or magazines about IVA test, more attention to counseling delivered midwife, seeking more information about IVA test so it can be interesting to follow the IVA test.

2. Health workers

Midwives are expected to support and provide complete information 
on the definition, benefits, risk factors, check the schedule, condition check, spot check and improve education about IVA test clearly and in detail. Husband included in counseling for husbands also know about the IVA test. It is expected that the public understand the importance of IVA test and participate following the IVA test.

3. Husband

The husband is expected to support further information, assessment, instrumental, and emotional. Foremost is more forthcoming with information about the IVA and IVA test accompanying his wife.

4. Further research

It is expected that there is a continuation of research on factors associated with participation IVA test with a larger number of samples to obtain significant results. Giving research a longer time, and adding variables associated with the IVA test more.

\section{References}

Aziz, A. (2011). the correlation between knowledge and attitude towards the actions of the pap smear and visual inspection acetate in women sex workers are not directly in the hotspot $\mathrm{x}$ Kecamtan Marpoyan peace pekanbaru as early detection of cervical cancer, 1-16. https://doi.org/10.1360/zd-201343-6-1064

Dewi, wawan and. (2011). theory and measurement of knowledge, attitudes, and human behavior. Yogyakarta: nuha medika.

Java, D. (nd). jateng health profile.

Lailawati, A. (2016). Pus In Doing screening visit Iva In the village of
Subdistrict Bojong Bojonglor Pekalongan District Nurses Study Program.

Lestari, IS (2016). Factors Affecting Willingness WUS in Cervical Cancer Early Detection options in Puskesmas Manahan Surakarta. Health Management Indonesia, 5 (2), 62-77.

Lisminawati, H. (2016). knowledge, interest and participation test counseling pacsa iva women about cervical cancer in the village caturharjo Yogyakarta Sleman, (45), 39.

Maharsie, L. (2013). relationship mother's knowledge about cervical cancer as the participation of mothers do iva test Jebres surakarta village. Increased Performance With Nurses In PNPM Implementation Supervision By Kepela room, 10 (1), 57-70. https://doi.org/10.1109/TAP.2014. 2313637

Masturoh, E. (2016). Factors - Factors Affecting Women of fertile age (WUS) in Cervical Cancer Early Detection Perform Visual Inspection Method Acetic Acid (VIA), 14. Retrieved from http://lib.unnes.ac.id/26206/1/641 1412056.pdf

melva, yusrawati Hasibuan, goddess meliasari. (2014). the influence of knowledge and attitudes about cervical cancer to the examination in women of childbearing age in the village of stone Pancur Tuntungan II sub-district in 2013, 3-6.https://doi.org/10.1016/S01889478(16)30123-2

Ning, luh made anggie rahayu. (2017). relationship with the husband's support in the area of health centers iva examination Pringapus Semarang regency, 91, 399-404. 
Notoatmodjo. (2010). health promotion. Jakarta: PT Rineka Reserved.

Parapat, FT, S, HS, Sc, M., Saraswati, LD, \& Epid, M. (2016). factors related to the behavior of the detection of cervical dinimkanker visual inspection method in the clinic Candiroto acetic acid Temanggung regency, 4, 363-370.

Rahayu. (2015). nurturing mother with cervical cancer. jakarta: Salemba Medika.

Rasjidi. (2009). Early detection of cancer prevention in women. jakarta: CV Sagung Seto.

RI, K. (nd). Indonesia's health profile.

Saputri. (2014). Faculty of Health Sciences

University

Muhammadiyah Surakarta

Phubungan 2014. Between

Knowledge About

Cataract Surgery Cataract

Patients And Economic

Levels With Attitude

About Cataract Surgery

Patients Cataracts In

Seniors In Ja Ker

Regional Health Center

Sukoharjo, 4.

https://doi.org/10.5897/AJ

EST2013. 1624

Sari, R. (2016). overview

husband support health

personnel in the

examination of a visual

inspection of acetic acid in

Temanggung district

temanggung health

centers, 57.

Savitri. (2015). completely

peeled breast cancer, cervix and uterus. Yogyakarta: new libraries press.

Waterford, the district health office. (2011). Temanggung district health profile.

https://doi.org/10.1360/zd2013-43-6-1064

Yustisianti, EN (2017). Relationship Support Husband With Female Behavior of fertile age (WUS) Perform Visual Inspection Inspection Acetic Acid (VIA) In Poor Health Center I Bantul. https://doi.org/10.1080/10 47840X.2014.878522 